\title{
Antimicrobial resistance in Pasteurella and Mannheimia: epidemiology and genetic basis
}

\author{
Corinna KeHREnBERG ${ }^{\mathrm{a}}$, Gundula Schulze-TANZIL ${ }^{\mathrm{a}}$, \\ Jean-Louis MARTEL ${ }^{\mathrm{c}}$, Elisabeth CHASLUS-DANCLA ${ }^{\mathrm{b}}$, \\ Stefan SCHWARZ ${ }^{\text {a* }}$ \\ a Institut für Tierzucht und Tierverhalten, Bundesforschungsanstalt für Landwirtschaft (FAL), \\ 29223 Celle, Germany \\ ${ }^{\mathrm{b}}$ Institut National de la Recherche Agronomique, Pathologie Aviaire et Parasitologie, \\ 37380 Nouzilly, France \\ c Agence Française de Sécurité Sanitaire des Aliments, Pathologie Bovine et Hygiène des viandes, \\ 31 avenue Tony Garnier, 69364 Lyon Cedex 07, France
}

(Received 23 November 2000; accepted 2 February 2001)

\begin{abstract}
Isolates of the genera Pasteurella and Mannheimia cause a wide variety of diseases of great economic importance in poultry, pigs, cattle and rabbits. Antimicrobial agents represent the most powerful tools to control such infections. However, increasing rates of antimicrobial resistance may dramatically reduce the efficacy of the antimicrobial agents used to control Pasteurella and Mannheimia infections. This review presents a short summary of the infections caused by Pasteurella and Mannheimia isolates in food-producing animals and the possibilities of preventing and controlling primary and secondary pasteurellosis. Particular reference is given to antimicrobial chemotherapy and the resistance properties of Pasteurella and Mannheimia isolates. The genetic basis of the most predominant resistance properties such as resistance to $\beta$-lactam antibiotics, tetracyclines, aminoglycosides, sulfonamides, and chloramphenicol is discussed. This is depicted with reference to the role of plasmids and transposons in the spread of the resistance genes among Pasteurellaceae and members of other bacterial families and genera.
\end{abstract}

antimicrobial resistance / Pasteurella / Mannheimia / plasmid / transposon / horizontal gene transfer

Résumé - Résistance aux antimicrobiens chez Pasteurella et Mannheimia : épidémiologie et bases génétiques. Les bactéries des genres Pasteurella et Mannheimia provoquent une grande variété de maladies ayant des conséquences économiques considérables chez les volailles, les porcs,

* Correspondence and reprints

Tel.: (49) 5141 384673; fax: (49) 5141 381849; e-mail: stefan.schwarz@fal.de 
les bovins et les lapins. Les antibiotiques représentent les outils les plus efficaces pour contrôler ces infections. Cependant, l'augmentation de la résistance aux antibiotiques pourrait réduire de manière dramatique leur efficacité dans le contrôle des infections à Pasteurella et Mannheimia. Cette revue de la littérature présente brièvement les infections causées par les Pasteurella et Mannheimia chez les animaux entrant dans la chaîne alimentaire, et les possibilités de prévenir et de contrôler les pasteurelloses primaires et secondaires. Une attention particulière est donnée à la chimiothérapie antimicrobienne et aux propriétés de résistance des Pasteurella et de Mannheimia. Les bases génétiques de la résistance aux $\beta$-lactamines, tétracyclines, aminosides, sulfamides et chloramphénicol, sont décrites avec une référence au rôle des plasmides et des transposons dans la propagation des gènes de résistance parmi les Pasteurellaceae et les membres d'autres familles et genres bactériens.

résistance aux antimicrobiens / Pasteurella / Mannheimia / plasmide / transposon / transfert horizontal de gène

\section{Table of contents}

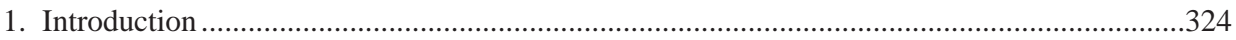

2. Taxonomy and pathogenicity of Pasteurella and Mannheimia ..............................................325

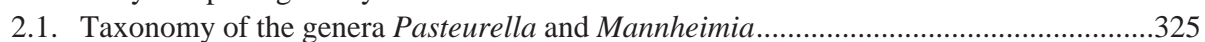

2.2. Pasteurella and Mannheimia isolates as primary and secondary pathogens...................325

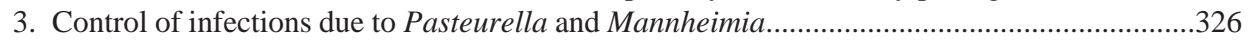

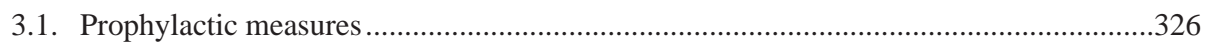

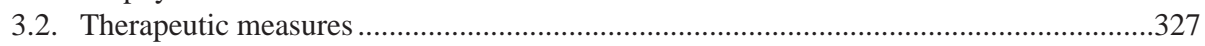

4. Antimicrobial resistance of Pasteurella and Mannheimia isolates .......................................328

4.1. Determination of antimicrobial resistance and epidemiological aspects ...........................328

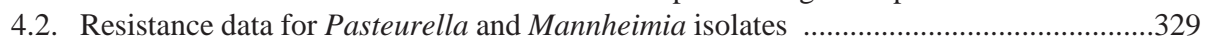

4.3. Genetic basis of antimicrobial resistance of Pasteurella and Mannheimia ......................330

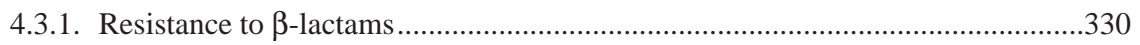

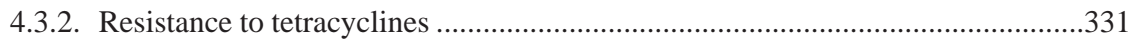

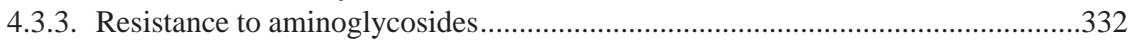

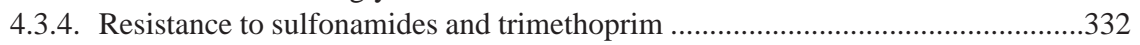

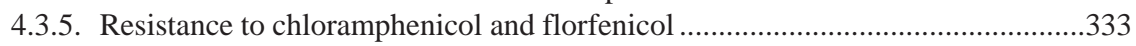

5. The role of horizontal gene transfer in the spread of antimicrobial resistance genes

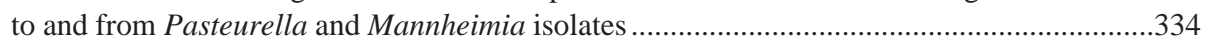

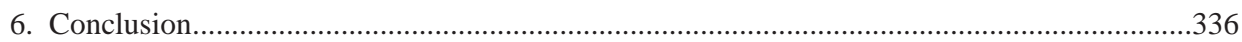

\section{INTRODUCTION}

Isolates of the genera Pasteurella and Mannheimia represent pathogens which are involved in a wide variety of infections in food-producing animals. Antimicrobials are still the tools of choice for prevention and control of infections due to Pasteurella and Mannheimia. However, imprudent use of antimicrobials bears a high risk of selecting resistant bacteria, promoting the spread of resistance genes located on plasmids and transposons, and consequently, reducing the efficacy of the antimicrobial agents currently available for the treatment of foodproducing animals. On the one hand, this review focuses on the possibilities to prevent and control infections due to Pasteurella and Mannheimia isolates in animals; on the other hand, data on resistance development among Pasteurella and Mannheimia are presented and the genetics of the respective resistance genes are described in detail. Most of the resistance 
genes currently known to be present in Pasteurella and Mannheimia are associated with mobile genetic elements. Since only few of these resistance genes appear to be indigenous to Pasteurella and Mannheimia, isolates of these two genera may acquire resistance genes from other bacteria by horizontal gene transfer. The data presented in this review will help to understand the processes involved in the acquisition, exchange, and further emergence of resistance genes among bacteria of the genera Pasteurella and Mannheimia. This calls for prudent use of antimicrobial agents to retain the efficacy of antimicrobials in the future.

\section{TAXONOMY AND PATHOGENICITY \\ OF PASTEURELLA \\ AND MANNHEIMIA}

\subsection{Taxonomy of the genera Pasteurella and Mannheimia}

The family Pasteurellaceae which currently comprises the five genera Pasteurella, Mannheimia, Actinobacillus, Haemophilus, and Lonepinella has been the subject of extensive reclassification in the past. In recent years, studies based on DNA-DNA hybridisations $[3,50]$ and comparisons of the nucleotide sequences of $16 \mathrm{~S}$ ribosomal RNA [3, 20] formed the basis for the current taxonomy of the genus Pasteurella, but also served to define the new genus Mannheimia with the new species Mannheimia $(M$.) haemolytica which includes bacteria formerly assigned to the biovar Arabinose within the Pasteurella (P.) haemolytica complex. The new species $P$. trehalos $i$ includes bacteria previously assigned to the biovar Trehalose within the $P$. haemolytica complex $[2,3]$. Thus the term " $P$. haemolytica" is used in this review when referring to isolates studied or data elaborated before the new genus Mannheimia was described. A continuously updated summary of the latest taxonomic developments within the five genera of the family Pasteurellaceae can be obtained from http://www.bacterio.cict.fr [23]. Although bacteria have been better defined at the species level, there is a growing awareness that a great variety of hostadapted serotypes or variants is present and the significance of their role in disease is now being examined.

The family Pasteurellaceae, including members of the genera Mannheimia, Pasteurella and Haemophilus, are natural inhabitants of the mucosal surfaces of vertebrates, particularly of ruminants, where they are able to survive in the upper part of the respiratory tract of clinically healthy animals and are occasionally involved in diseases. Table I shows the species currently assigned to the genera Pasteurella and Mannheimia, their major habitats and their association with diseases in animals and humans.

\subsection{Pasteurella and Mannheimia isolates as primary and secondary pathogens}

As a primary pathogen and in tropical countries $P$. multocida is responsible for "haemorragic septicaemia of cattle and water buffaloes": Capsular type B occurs in Africa, the Middle East and Asia, and capsular type E in West, Central and South Africa. Bacteria assigned to the new species P. trehalosi, capsular types T3, T4, and T10 are encountered world-wide in sheep and goats where they cause severe septicaemia in young animals. In other animal species, $P$. multocida isolates can also act as primary pathogens; the corresponding diseases include fowl cholera and snuffles in rabbits $[7,53]$. As secondary pathogens, bacteria within the family Pasteurellaceae play a major role in the final progression to severe pleuropneumonia in cattle, sheep and goats where "pasteurellosis" is often synonymous with "respiratory disease", but also in enzootic pneumonia and progressive atrophic rhinitis of swine, as well as pasteurellosis in small laboratory rodents and 
Table I. Species within the genera Pasteurella and Mannheimia [43], their major habitats and their association with diseases in humans and animals.

\begin{tabular}{|c|c|c|}
\hline Species & Habitat & Clinical relevance \\
\hline P. aerogenes & $\begin{array}{l}\text { physiological flora of oropharynx } \\
\text { and intestinal tract of pigs }\end{array}$ & $\begin{array}{l}\text { abortion, stillbirth in pigs, } \\
\text { dogs, rabbits }\end{array}$ \\
\hline P. anatis & physiological flora of ducks & - \\
\hline P. avium & respiratory tract of poultry & - \\
\hline P. bettyae & genital tract of humans & infections of the urogenital tract \\
\hline P. caballi & respiratory tract of horses & pneumonia, peritonitis \\
\hline P. canis & respiratory tract of calves and dogs & infections after bites \\
\hline P. dagmatis & respiratory tract of cats and dogs & infections after bites \\
\hline P. gallinarum & respiratory tract of chickens & - \\
\hline P. langaaensis & respiratory tract of poultry & - \\
\hline P. mairii & genital tract of pigs & abortion, sepsis in piglets \\
\hline $\begin{array}{l}\text { P. multocida subsp. } \\
\text { multocida, septica } \\
\text { and gallicida }\end{array}$ & $\begin{array}{l}\text { respiratory tract of mammals } \\
\text { and birds }\end{array}$ & $\begin{array}{l}\text { infections of the respiratory } \\
\text { tract, septicaemia }\end{array}$ \\
\hline$P$. pneumotropica & $\begin{array}{l}\text { respiratory tract of guinea pigs, } \\
\text { hamsters, rats, cats and dogs }\end{array}$ & $\begin{array}{l}\text { pneumonia, conjunctivitis, } \\
\text { ataxia }\end{array}$ \\
\hline P. stomatis & respiratory tract of cats and dogs & infections after bites \\
\hline P. testudinis & respiratory tract of desert tortoises & $\begin{array}{l}\text { infections of the upper } \\
\text { respiratory tract }\end{array}$ \\
\hline P. trehalosi & respiratory tract of ruminants & septicaemia \\
\hline P. volantium & respiratory tract of poultry & - \\
\hline M. haemolytica & respiratory tract of ruminants & pneumonia, septicaemia, mastitis \\
\hline M. glucosida & respiratory tract of ruminants & - \\
\hline M. granulomatis & $\begin{array}{l}\text { respiratory tract of domestic } \\
\text { and wild ruminants, hares }\end{array}$ & $\begin{array}{l}\text { pneumonia, conjunctivitis, } \\
\text { panniculitis }\end{array}$ \\
\hline M. ruminalis & physiological ruminal flora & - \\
\hline M. varigena & $\begin{array}{l}\text { respiratory tract and intestinal } \\
\text { tract of ruminants and pigs }\end{array}$ & $\begin{array}{l}\text { pneumonia, mastitis, enteritis, } \\
\text { septicaemia }\end{array}$ \\
\hline
\end{tabular}

* In addition to the species recognised so far, several unnamed taxa have been described in the genus Mannheimia [3].

fur-bearing animals $[7,53]$. It is generally recognised that these Pasteurella infections are multifactorial and multi-agent diseases involving viruses (Parainfluenza virus 3, Bovine Herpes virus 1, Bovine Respiratory Syncytial virus in cattle), Mycoplasma spp. (M. bovis in cattle, M. hyopneumoniae in pigs) and bacteria such as Pasteurellaceae, but also Arcanobacterium pyogenes in cattle, and Bordetella bronchiseptica in pigs. Under predisposing environmental conditions and/or management conditions which constitute stress for the animals, such as transport (shipping fever), marketing, change of feed, climate or ventilation, viruses and/or Mycoplasma spp. are determining in initi- ating a pathological process commonly accompanied by a high morbidity but low mortality. Great economic losses are a result of the retarded growth rate of the affected animals [53].

\section{CONTROL OF INFECTIONS \\ DUE TO PASTEURELLA \\ AND MANNHEIMIA}

\subsection{Prophylactic measures}

Most of the animal diseases involving isolates of the genera Pasteurella and 
Mannheimia represent diseases which are mainly influenced by a wide variety of environmental and management risk factors. Thus the reduction or even elimination of such predisposing factors is of major importance. Non-immunoprophylactic measures such as optimised management, but also optimised hygienic, climatic and feeding conditions may be supported by the use of vaccines. To date, there are very few Pasteurella and Mannheimia vaccines available for the different animal species, all of which are inactivated vaccines.

Problems with vaccination arise from the observation that there are more than one serotype of a certain species, e.g. $M$. haemolytica, involved in diseases in the respective animals, and that some vaccines may lack host-adapted type capsular polysaccharides. Therefore, information on capsular serotypes must also be taken into consideration in developing effective vaccines. In the case of $M$. haemolytica, serotype A1 is the most commonly isolated serotype from pneumonic lungs of cattle and generally the unique serotype introduced into commercial vaccines. We have drawn attention to this point in order to adapt the composition of the vaccine according to the target animal species, indicating the difference of serotype distribution in cattle, sheep and goats [46]. In addition, we are now observing that isolation of serotype A6 is increasing in the UK [21], in France (Martel, unpublished results) and in North America [52]. Unfortunately, serotyping is not carried out routinely due to the lack of commercially available antisera. Therefore, inadequacy between the composition of vaccines in terms of bacterial species and capsular serotypes, and the local epidemiological situation may be the main cause of the failure to protect. As a consequence of the ineffectiveness of vaccination, clinical diseases may occur more frequently and require effective treatment of the diseased animals.

\subsection{Therapeutic measures}

The control of ongoing infections with Pasteurella and Mannheimia isolates is difficult for two reasons: (a) in most of these infections, the Pasteurella and Mannheimia isolates are not the only causative agents and even with the successful control of the Pasteurella and Mannheimia isolates involved, there is no complete cure for the cause of the disease, (b) bacteria of the genera Pasteurella and Mannheimia exhibit increasing resistance to a large number of antimicrobial agents available for use in the respective animal species. Because of the rapid spread of resistance, the antimicrobial sensitivity of the Pasteurella and Mannheimia isolates should be tested and a suitable antibiotic should be chosen on the basis of the in vitro sensitivity. However, taking a sample, sending it to a diagnostic laboratory, isolating the Pasteurellaceae and testing their in vitro sensitivity usually takes several days during which the disease can progress dramatically. Therefore, it is commonly required to start the therapy immediately. For the choice of the antibiotics, veterinary surgeons often rely on recommendations based on the resistance data obtained from the national monitoring programmes [9] or on recommendations which are given in the different textbooks. The latter recommendations include, for almost all animal species, sulfonamides, tetracyclines and streptomycin. Chloramphenicol, which was recommended in the older textbooks was banned from use in food-producing animals in 1994 and has since been replaced by florfenicol which was licensed for the treatment of bovine respiratory diseases in 1995.

Selective pressure by antimicrobial agents, which favours the emergence of resistant isolates represents a serious problem, particularly in developed countries where domestic ruminants are reared in intensive units. That is the reason why in France Pasteurellaceae have been included in the national network for the monitoring of 
antimicrobial resistance within the main pathogenic bacteria for cattle [47]. To date, $M$. haemolytica is the most frequent pathogen isolated from bovine pneumonic lungs and is generally more resistant to antibiotics than $P$. multocida, and isolates of $H$. somnus are generally the most sensitive. $M$. haemolytica isolates from sheep and goats, that are less commonly reared in intensive conditions, are generally less resistant to antibiotics than M. haemolytica isolates from cattle.

\section{ANTIMICROBIAL RESISTANCE OF PASTEURELLA AND MANNHEIMIA ISOLATES}

\subsection{Determination of antimicrobial resistance and epidemiological aspects}

Antimicrobial resistance of Pasteurella and Mannheimia isolates varies according to the host animal species, time, geographical origin and antimicrobial pretreatment of the animals. It also depends on the access of the Pasteurella and Mannheimia isolates to the resistance genes present in the respective gene pools and on the horizontal gene transfer mechanisms available within these gene pools. Moreover, data on antimicrobial resistance may also vary based on differences in the methodology of resistance testing and the breakpoints for resistance as laid down in the standards used in different countries, such as Deutsche Industrienorm (DIN) 58940 (Germany), National Committee for Clinical Laboratory Standards (NCCLS) document M31-A (USA), and Comité de l'Antibiogramme de la Société Française de Microbiologie (CA-SFM) (France). Striking differences in the numbers of isolates tested and the lack of data on epidemiological relatedness of the isolates make it difficult to compare the data on antimicrobial resistance of Pasteurella and Mannheimia isolates determined in different countries. Isolates of the genera Pasteurella and
Mannheimia are investigated for their antimicrobial resistance properties in the national monitoring programmes of only five European countries (see Concerted Action Fair 5-CT97-3654, Antibiotic resistance in bacteria of animal origin, http://www.fougeres.afssa.fr/arbao): France, Germany, the UK, the Netherlands, and Portugal $[9,47]$. Another often underestimated problem arises from the species identification and differentiation of bacteria assigned to these two genera. In contrast to bacteria of other families and genera, there is no commercially available system that is easy to use and does not require specific expensive equipment. An additional problem in the resistance statistics of Pasteurella and Mannheimia isolates is the multiple inclusion of the same isolate in such statistics. Routinely, diagnostic laboratories do not perform a differentiation of isolates in addition to resistance testing. Thus isolates of the same clone which are spread within a certain geographical area may be mistakenly handled as unrelated isolates and their resistance data may be included several times in each set of statistics. As with many other bacterial pathogens, differentiation of single isolates is achieved most efficiently by applying molecular methods [8, 14, 41]. Various methods are available and have been used successfully for the differentiation of Pasteurella and Mannheimia isolates: plasmid profiling, ribotyping, various PCR techniques, and macrorestriction analysis (for a review see [8, 33]). While these techniques have most often been used to differentiate between pathogenic and toxigenic isolates, but also for taxonomic and epidemiological purposes, they have rarely been used in relation to antimicrobial resistance. Recently, macrorestriction analysis (Fig. 1) served to determine the relatedness of chromosomally tetracycline-resistant $P$. aerogenes isolates [35-37], but also to prove the horizontal transfer of tetracycline resistance plasmids between $P$. multocida and $P$. aerogenes isolates from pigs [36]. 
$\begin{array}{llllllllll}M & 1 & 2 & 3 & 4 & 5 & 6 & 7 & 8 & M\end{array}$

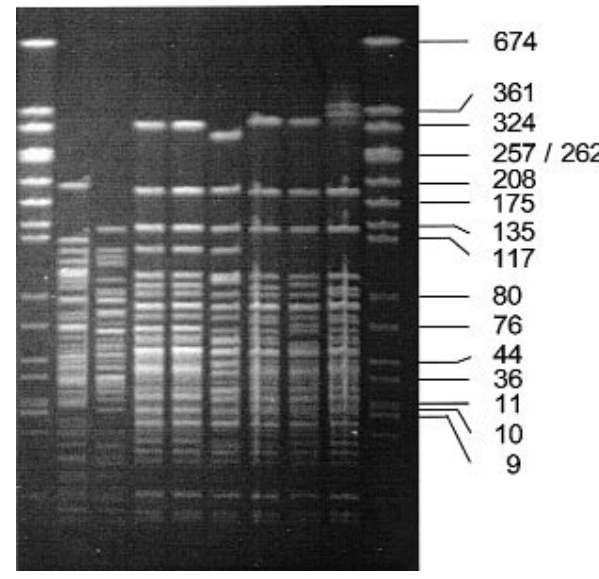

Figure 1. SmaI macrorestriction patterns of $P$. aerogenes (lanes 1,2 ) and $P$. multocida isolates (lanes 3-8) harbouring the tet $(\mathrm{H})$-carrying Tc resistance plasmid pPAT1 [36]. Lanes M contain the SmaI fragments of Staphylococcus aureus NCTC 8325. Sizes of the marker fragments are given in $\mathrm{kb}$ on the right hand side.

\subsection{Resistance data for Pasteurella and Mannheimia isolates}

Data obtained from Germany and France, in 1997, are summarised in Table II.

These data illustrate that there is a high degree of variability among isolates assigned to different genera (e.g. P. multocida vs. " $P$. haemolytica"), but originating from the same animal source (e.g. cattle). The data obtained from the continuous monitoring of isolates from year to year from one country, for example in the case of Germany, shows that the resistance rates may also vary over time (Tab. III). Nevertheless, percentages of resistant isolates also vary between the older and newer molecules in each family. In both countries, resistance to the newer cephalosporins (ceftiofur, cefquinome) and to florfenicol has not yet been encountered. The large majority of strains are still susceptible to the fluoroquinolone enrofloxacin. For macrolides, the therapeutic breakpoints proposed by the national committees are not

Table II. Antimicrobial susceptibility (in \%) among bovine P. multocida and "P. haemolytica" isolates obtained in 1997 in Germany and France.

\begin{tabular}{|c|c|c|c|c|c|c|}
\hline \multirow{2}{*}{$\begin{array}{l}\text { Antimicrobial } \\
\text { agents }\end{array}$} & \multicolumn{3}{|c|}{ Germany $^{\mathrm{a}}$} & \multicolumn{3}{|c|}{ France $^{\mathrm{b}}$} \\
\hline & $\begin{array}{l}\text { Diameter zone } \\
\left(\mathrm{MIC}, \mu \mathrm{g} \cdot \mathrm{mL}^{-1}\right)^{\mathrm{c}}\end{array}$ & $\begin{array}{c}P . \\
\text { multocida }\end{array}$ & $\begin{array}{c}\text { "P. } \\
\text { haemolytica" }\end{array}$ & $\begin{array}{l}\text { Diameter zone } \\
\left(\mathrm{MIC}, \mu \mathrm{g} \cdot \mathrm{mL}^{-1}\right)^{\mathrm{d}}\end{array}$ & $\begin{array}{c}P . \\
\text { multocida }\end{array}$ & $\begin{array}{c}\text { "P. } \\
\text { haemolytica" }\end{array}$ \\
\hline Penicillin G & $24(0.125)$ & $82(242)^{\mathrm{e}}$ & 69 (212) & $29(0.25)$ & $39(180)$ & $10(342)$ \\
\hline Ampicillin & $22(2)$ & $89(476)$ & $78(461)$ & $19(4)$ & $90(678)$ & $40(1000)$ \\
\hline Streptomycin & $15(4)$ & $33(396)$ & $22(396)$ & $15(8)$ & 37 (604) & $6(834)$ \\
\hline Tetracycline & $22(1)$ & $71(493)$ & $68(469)$ & $19(4)$ & $64(804)$ & $39(1015)$ \\
\hline Chloramphenicol & $21(8)$ & 88 (137) & 87 (142) & $23(8)$ & $74(566)$ & $65(877)$ \\
\hline Nalidixic acid & - & n.d. & n.d. & $20(8)$ & $83(423)$ & $71(577)$ \\
\hline Sulfonamides & $16(16)$ & $17(215)$ & 27 (184) & $17(100)$ & $34(608)$ & 19 (935) \\
\hline Sulfonamides/ & $16(16 / 08)$ & $4(474)$ & $82(461)$ & $16(128 / 8)$ & $85(617)$ & $68(834)$ \\
\hline
\end{tabular}

a Data from pathological samples, collected in 1997 from Trolldenier [65] and the Concerted Action FAIR 5-CT973654.

b Data from pathological samples, cumulated in 1997 from Resabo [47].

c Evaluation of the diameters of the zones of growth inhibition followed DIN recommendations except for streptomycin where NCCLS guidelines were used.

${ }^{\mathrm{d}}$ Evaluation of the diameters of the zones of growth inhibition followed the CA-SFM recommendations.

e Numbers in parentheses indicate the numbers of isolates tested. 
Table III. Percentages of susceptible bovine $P$. multocida and bovine " $P$. haemolytica" isolates from Germany 1990-1996 according to [61-65].

\begin{tabular}{|c|c|c|c|c|c|c|c|c|c|c|}
\hline \multirow[t]{2}{*}{ Year } & \multirow[t]{2}{*}{$\mathrm{n}^{\mathrm{a}}$} & \multicolumn{9}{|c|}{ Antimicrobial agents ${ }^{b}$} \\
\hline & & Amp & Pen & $\mathrm{Tc}$ & $\mathrm{Cm}$ & $\mathrm{Sm}$ & $\mathrm{Nm}$ & $\mathrm{Gm}$ & Sul-3 & SxT \\
\hline \multicolumn{11}{|c|}{ P. multocida } \\
\hline 1990 & 184 & $-{ }^{c}$ & 81 & 87 & 82 & 52 & 86 & - & 36 & - \\
\hline 1991 & 310 & 87 & 76 & 81 & 77 & 42 & 77 & 74 & 27 & 69 \\
\hline 1992 & 471 & 90 & 89 & 70 & 77 & 39 & 58 & 71 & 25 & 85 \\
\hline 1993 & 428 & 90 & 87 & 59 & 73 & 27 & 45 & 51 & 16 & 79 \\
\hline 1994 & 488 & 90 & 81 & 74 & 80 & 35 & 64 & 45 & 26 & 84 \\
\hline 1995 & 685 & 91 & 71 & 77 & 81 & 42 & 64 & 38 & 23 & 77 \\
\hline 1996 & 560 & 90 & 66 & 70 & 72 & 38 & 56 & 51 & 14 & 70 \\
\hline \multicolumn{11}{|c|}{ "P. haemolytica" } \\
\hline 1990 & 300 & - & 89 & 91 & 89 & 62 & 97 & - & 47 & - \\
\hline 1991 & 217 & 71 & 75 & 75 & 71 & 42 & 83 & 81 & 53 & 73 \\
\hline 1992 & 536 & 70 & 71 & 50 & 68 & 31 & 68 & 72 & 43 & 85 \\
\hline 1993 & 580 & 68 & 68 & 59 & 71 & 26 & 62 & 52 & 26 & 75 \\
\hline 1994 & 572 & 71 & 65 & 62 & 79 & 23 & 65 & 41 & 29 & 82 \\
\hline 1995 & 757 & 70 & 48 & 68 & 77 & 32 & 65 & 37 & 19 & 84 \\
\hline 1996 & 535 & 68 & 45 & 67 & 70 & 21 & 54 & 49 & 17 & 74 \\
\hline
\end{tabular}

$\mathrm{n}=$ numbers of isolates investigated.

b Abbreviations of antimicrobial agents: Amp (ampicillin), Pen (penicillin G), Tc (tetracycline), Cm (chloramphenicol), Sm (streptomycin), Nm (neomycin), Gm (gentamicin), Sul-3 (sulfadiazin, sulfamerazin, sulfamethazin), SxT (sulfamethoxazole/trimethoprim)

$c_{-}=$no data available.

pertinent for both therapeutic and monitoring purposes. However, we observe that erythromycin, spiramycin, tylosin, and tilmicosin are still active to date.

\subsection{Genetic basis of antimicrobial resistance of Pasteurella and Mannheimia}

\subsubsection{Resistance to $\beta$-lactams}

Resistance to $\beta$-lactams among $P$. multocida isolates is often mediated by small plasmids of 4.1-4.4 kb [44, 54]. The occurrence of similar-sized $\beta$-lactam resistance plasmids of 4.2-5.2 kb in " $P$. haemolytica" isolates has also been reported $[4,11,12$, $17,49,55,57]$. These resistance plasmids were commonly identified by transformation experiments using $E$. coli strains as recipients. Several of these $\beta$-lactam resistance plasmids down-regulated their copy number in some of the E. coli hosts, however without negative effects on the level of $\beta$-lactam resistance $[4,17,44,56,68]$. Whenever molecular analyses were performed to identify the type of the $\beta$-lactamase (bla) gene, the gene bla $a_{\mathrm{ROB} 1}$ was detected $[4,44]$. The ROB1- $\beta$-lactamase is a member of the Ambler Class A ( = Bush class 2 b) $\beta$-lactamases which are highly sensitive to inhibition by $\beta$-lactamase inhibitors and mediate resistance to penicillins and 1 st generation cephalosporins [60].

The ROB1- $\beta$-lactamase was first described in a $H$. influenzae type b meningitis isolate from a child in USA. The corresponding $b l a_{\mathrm{ROB} 1}$ gene was on a plasmid of $4.4 \mathrm{~kb}$. Later on, the ROB1 enzyme was detected in porcine Actinobacillus pleuropneumoniae isolates throughout the USA, and 
in bovine and porcine $P$. multocida, $P$. haemolytica and $P$. aerogenes in France $[44,45,48,51]$. In all the bovine strains of Pasteurella studied at that time, the bla $a_{\mathrm{ROB} 1}$ genes were present on plasmids of $4.1 \mathrm{~kb}$ except in one strain of $P$. haemolytica harbouring a plasmid of $4.4 \mathrm{~kb}$. Such $4.4 \mathrm{~kb}$ plasmids were also encountered in $H$. influenzae strains. The bla $a_{\mathrm{ROB} 1}$ encoding plasmids from Pasteurella and Haemophilus strains were compared by hybridisation and restriction endonuclease analysis resulting in the hypothesis of a close genetic relationship between the 4.1 and $4.4 \mathrm{~kb}$ plasmids. In $P$. aerogenes, the $b l a_{\mathrm{ROB} 1}$ gene was present on the chromosome [44].

So far, five $b l a_{\mathrm{ROB} 1}$ gene sequences are known: two from " $P$. haemolytica" (database accession numbers: X52872, Z21724), two from Actinobacillus (A.) pleuropneumoniae (AB034202; S51028 or M97481), and one from Haemophilus (H.) influenzae (AF022114). All ROB1- $\beta$-lactamase protein sequences of 305 amino acids (aa) are identical [34, 44, 45, 48]. The sequence of ROB 1 protein was compared with the sequences of other class A $\beta$-lactamases and showed about $40 \%$ homology with all the known class A enzymes. The ROB 1 enzyme exhibited the highest similarity to the $\beta$-lactamases from gram-positive bacteria and appeared as a possible link between the $\beta$-lactamases of gram-positive and gram-negative bacteria [45].

\subsubsection{Resistance to tetracyclines}

Tetracycline resistance genes of the three different hybridisation classes $\mathrm{H}, \mathrm{B}$, and $\mathrm{M}$ have been identified among members of the genera Pasteurella and Mannheimia. The gene $\operatorname{tet}(\mathrm{M})$ is the most widespread tet gene among gram-positive and gram-negative bacteria. It has been identified as part of a number of conjugative transposons in grampositive cocci, but has in the meantime been observed in a wide variety of gram-positive and gram-negative bacteria [15]. So far, the gene $\operatorname{tet}(\mathrm{M})$ has been detected by hybridis- ation in the chromosomal DNA of two bovine $P$. multocida isolates, one from France [13] and the other from the USA [27]. The tet(B) gene is part of the non-conjugative transposon Tn10 [10] and represents the most frequently observed tet gene among Enterobacteriaceae. To date, this gene has been detected in a single bovine " $P$. haemolytica" isolate from France [13] and in two porcine $P$. multocida isolates from the USA and Germany [35]. However, the tet(B) gene proved to be the predominant tet gene among $P$. aerogenes isolates of porcine sources [37]. Hybridisation patterns obtained from SfuI-digested whole cellular DNA of the $P$. multocida and $P$. aerogenes isolates points towards the presence of complete copies of $\mathrm{Tn} 10$ in the majority of the isolates investigated [37]. The gene $\operatorname{tet}(\mathrm{H})$ was originally detected on plasmid pVM111 from an avian $P$. multocida isolate from the USA [26], but later also in the chromosomal DNA and on plasmids of $P$. multocida and "P. haemolytica" from porcine and bovine sources in North America [27]. Because of its plasmid and chromosomal location, the tet $(\mathrm{H})$ gene was assumed to be associated with a transposable element [27]. This assumption was proven by the identification of Tn5706, a non-conjugative composite transposon of 4378 bp (Fig. 2) which is located on plasmid pPMT1 from bovine $P$. multocida obtained in Germany [38]. The tetR-tet $(\mathrm{H})$ gene region in Tn5706 is bracketed by copies of two almost identical insertion elements, IS1596 and IS1597 (Fig. 2). Tn5706 is the first and so far only known transposon originally identified among members of the genus Pasteurella [33]. Truncated Tn5706 elements were also identified on the $4.4 \mathrm{~kb}$ plasmid pMHT1 from $M$. haemolytica [39] and the $5.5 \mathrm{~kb}$ plasmid pPAT1 which was observed in $P$. aerogenes and $P$. multocida [36]. All currently known TetH proteins (U00792; Y15510; Y16103; AJ245947) differ slightly from one another. The TetH protein of plasmid pPAT1, however, lacks the terminal 8 aa due to a recombination between the tet $(\mathrm{H})$ gene and the 


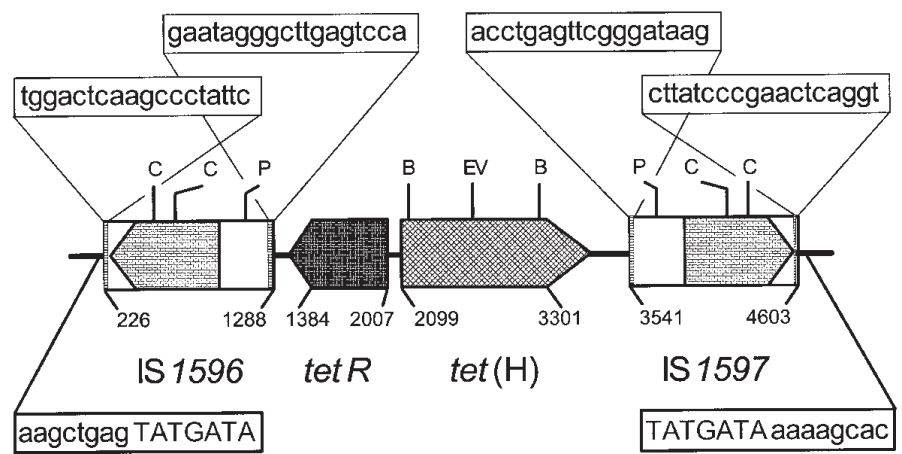

Figure 2. Organisation of transposon $\mathrm{Tn} 5706$, consisting of the tetR-tet $(\mathrm{H})$ resistance gene region bracketed by the insertion elements IS1596 and IS1597. The numbers below the respective elements and genes refer to the positions within the 4828 bp region of plasmid pPMT1 deposited in the databases (Y15510). The arrow-shaped boxes indicate the directions of transcription of the genes tet $(\mathrm{H})$ and tetR as well as the genes coding for the putative transposases of IS1596 and IS1597. The $18 \mathrm{bp}$ perfect, invertedly repeated sequences at the ends of the insertion elements, are displayed in boxes above the IS elements. The $7 \mathrm{bp}$ directly repeated sequences at the integration site are shown in capital letters, the adjacent pPMT1 sequences in lower case letters below the map of Tn5706. Cleavage sites for restriction endonucleases are abbreviated as follows: B $(B c l \mathrm{I}), \mathrm{C}(\mathrm{Cla} \mathrm{I}), \mathrm{EV}(\mathrm{EcoRV})$ und $\mathrm{P}(\mathrm{PvuII})$.

adjacent IS1597 sequence [36]. This terminal deletion, however, had no influence on the level of Tc resistance mediated by the respective TetH efflux system.

\subsubsection{Resistance to aminoglycosides}

Molecular analyses of aminoglycoside resistance in Pasteurella and Mannheimia focussed on streptomycin resistance. The first reports on transferable streptomycin resistance were published in 1978 by Berman and Hirsh [6]. This resistance property was mainly associated with small plasmids of less than $10 \mathrm{~kb}$ in P. multocida from turkeys, pigs and cattle, but also in " $P$. haemolytica" from cattle $[6,12,16$, 29-31, 58, 59, 67, 68]. However, a large conjugative plasmid of approximately $113 \mathrm{~kb}$ which mediated resistance to streptomycin, kanamycin, tetracycline and sulfonamides has also been identified [31]. The gene mediating streptomycin resistance, strA, codes for an aminoglycoside- 3'-phosphotransferase (E.C. 2.7.1.-) which enzymatically inactivates streptomycin. This gene has been found to be part of transposon Tn5393 from Erwinia amylovora (M95402; M96392), but virtually identical strA genes have also been identified on plasmids or in the chromosome of a wide range of bacteria including $P$. multocida (U57647), "P. haemolytica" (M83717; B56649), Haemophilus ducreyi (L23118), Mannheimia spp. (AJ249249), Pseudomonas (Ps.) aeruginosa (AF024602), Ps. syringae (M77502), Yersinia pestis (AJ249779), E. coli (M28829; JH0123), Xanthomonas campestris (U20588), as well as Corynebacterium striatum (AF024666) and uncultured eubacteria (AJ271879; AJ293027). All these phosphotransferase proteins consist of 267 aa and differ by up to 8 aa which corresponds to identities of $97-100 \%$.

\subsubsection{Resistance to sulfonamides and trimethoprim}

Sulfonamide resistance is one of the most often detected resistance properties among Pasteurella and Mannheimia isolates (Tabs. II and III). It is commonly mediated 
by the gene sulII which codes for a type II dihydropteroate synthase (E.C. 2.5.1.15) of 271 aa. Most of the currently known sulII genes have been detected in members of the family Pasteurellaceae, such as P. multocida (U57647), "P. haemolytica" (A56649; M83717), H. ducreyi (L23118), but have also been detected on conjugative or broad host range plasmids, such as pGS05 (M36657) and RSF1010, as well as on plasmids obtained from E. coli (A34950), Photobacterium $(P h$.) damselae subsp. piscicida (D37825), and uncultured eubacteria (AJ271879; AJ293027). Most of the sulII genes detected in bovine "P. haemolytica" and $P$. multocida isolates from poultry, pigs and cattle are located on plasmids which vary in size between 4.2 and $16.7 \mathrm{~kb}[6,12$, 16, 24, 29-31, 59, 67], some of which also mediate streptomycin, kanamycin and/or tetracycline resistance $[31,67]$.

Trimethoprim resistance is commonly due to dihydrofolate reductases. Trimethoprim resistance with MIC values of more than $16 \mu \mathrm{g} \cdot \mathrm{mL}^{-1}$ is rarely encountered among $P$. multocida and " $P$. haemolytica" isolates (Tabs. II and III). Studies on trimethoprimresistant bovine "P. haemolytica" isolates from France showed that trimethoprim resistance was not associated with plasmids and also was not transferable by conjugation. Hybridisation experiments with gene probes specific for the genes $d h f r$ I through $d h f r \mathrm{~V}$ did not yield positive results [22] suggesting that other determinants are responsible for trimethoprim resistance in Mannheimia isolates. These strains were simultaneously resistant to the O/129 component (2,4-diamino.6,7-diisopropyl-pteridine) used for the identification of Pasteurella. In such situations, resistance to the O/129 component could result in misidentification of trimethoprim-resistant Pasteurella.

\subsubsection{Resistance to chloramphenicol and florfenicol}

Chloramphenicol resistance is mainly mediated by chloramphenicol acetyltrans- ferases (E.C. 2.3.1.28), many of which are located on plasmids or transposons. Plasmids mediating chloramphenicol resistance have been identified in porcine $P$. multocida isolates [67], but also in bovine $P$. multocida and "P. haemolytica" isolates [66]. The first detailed studies on the genetic basis of chloramphenicol resistance among Pasteurella and Mannheimia isolates were conducted by Vassort-Bruneau et al. [66]. They designed PCR primers specific for the three most frequently occurring cat genes among gram-negative bacteria, catAI - catAIII, and detected catAI as well as catAIII genes among bovine $P$. multocida and " $P$. haemolytica" isolates [66]. The catAIII gene proved to be located on small plasmids of $5.1 \mathrm{~kb}$ while the catAI gene was located on plasmids of either 17.1 or $5.5 \mathrm{~kb}$ [66]. Plasmid-borne catAIII genes have also been detected in porcine $P$. aerogenes and bovine Mannheimia isolates by PCR (Fig. 3) (Kehrenberg and Schwarz, unpublished data). Recently, a small plasmid of $4992 \mathrm{bp}$ detected in a bovine Mannheimia isolate of unnamed taxon 10 was completely

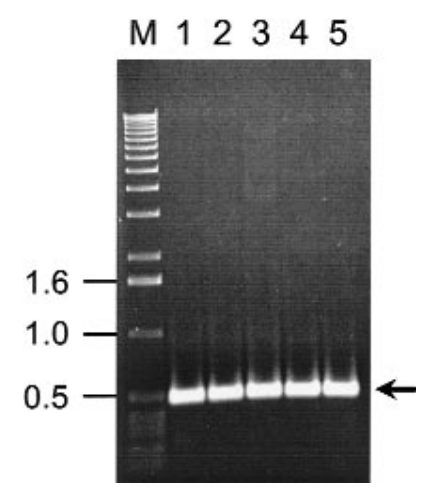

Figure 3. PCR detection of the chloramphenicol resistance gene catAIIII. The arrow indicates the position of the $473 \mathrm{bp}$ amplicon seen in five unrelated Pasteurella and Mannheimia isolates (lanes 1-5). Lane M contains the DNA size standard (1 kb ladder, Gibco-BRL) of which the sizes of some fragments are given in $\mathrm{kb}$ on the lefthand side. 
sequenced (database accession no. AJ 249249). This plasmid mediated resistance to sulfonamides by sulII, to streptomycin by strA and to chloramphenicol by catAIII (Kehrenberg and Schwarz, unpublished data). The catAI gene which codes for a CAT monomer of 219 aa was first identified on transposon Tn9 [1]. Similar or identical catAI genes have also been detected on plasmids or in the chromosomal DNA of Acinetobacter (A.) baumannii (M62822), A. calcoaceticus (M37690) and Ph. damselae subsp. piscicida (D16171). In comparison to catAI, the catAIII gene codes for a slightly smaller CAT monomer of 213 aa. Several catAIII genes virtually identical to that from Mannheimia taxon 10 have been found on plasmid R387 in Shigella flexneri and E. coli (X07848; P00484), but also on plasmids obtained from uncultured eubacteria (AJ271879; AJ293027). None of the chloramphenicol resistance plasmids detected so far in Pasteurella and Mannheimia isolates mediated resistance to the fluorinated chloramphenicol derivative, florfenicol. Florfenicol resistance has rarely - if at all - been detected among Pasteurella and Mannheimia isolates. A gene designated $p p$ flo (D37826) was detected in the fish pathogen Pasteurella piscicida [40] which has recently been re-classified as $P h$. damselae subsp. piscicida [25]. So far, no florfenicol resistance genes have been identified among isolates currently assigned to the genera Pasteurella and Mannheimia.

\section{THE ROLE OF HORIZONTAL GENE TRANSFER IN THE SPREAD OF ANTIMICROBIAL RESISTANCE GENES TO AND FROM PASTEURELLA AND MANNHEIMIA ISOLATES}

Most of the resistance genes to date encountered among Pasteurella and Mannheimia isolates are associated with either small plasmids (e.g. bla $a_{\mathrm{ROB} 1}$, strA,
sulII, catAIII), or with conjugative (e.g. tet $(\mathrm{M}))$ and non-conjugative transposons (e.g. $\operatorname{catAI}, \operatorname{tet}(\mathrm{H}), \operatorname{tet}(\mathrm{B}))$. For their replication, transposons depend on replicationproficient vector molecules of the host cell, such as chromosomal DNA or plasmids, in which they can integrate. Consequently, the transposon-borne tet genes of classes B, H, and $\mathrm{M}$ have been detected in the chromosomal DNA of Pasteurella and/or Mannheimia isolates [13, 35, 37, 39]. In some cases, transposon-borne $\operatorname{tet}(\mathrm{H})$ and tet(B) genes, but also catAIII genes were located on small plasmids of Pasteurella and Mannheimia isolates. Most of the resistance plasmids identified so far among Pasteurella and Mannheimia isolates exhibit sizes of less than $10 \mathrm{~kb}$ and are thus too small to carry the tra gene complex which is essential for conjugative transfer. Nevertheless, some of these plasmids have been shown to harbour up to three different $m o b$ genes (Kehrenberg and Schwarz, unpublished data) whose products enable horizontal transfer by mobilisation in the presence of a co-resident conjugative element. Since the Mob proteins originating from one plasmid may be used for the mobilisation of all plasmids of the same bacterial cell provided these plasmids carry an "origin of transfer" (oriT) -, plasmids which do not harbour mob genes can also be mobilized. Mobilisation is also the most reasonable explanation for the occurrence of indistinguishable type pPAT1 tet $(\mathrm{H})$-carrying plasmids in porcine $P$. multocida and $P$. aerogenes isolates [36], but also for the presence of identical plasmid-borne bla $a_{\mathrm{ROB} 1}$ genes in members of the genera Pasteurella [44, 45], Actinobacillus [34], and Haemophilus $[18,48]$. Conjugative plasmids not associated with antimicrobial resistance, but promoting mobilisation of co-resident small resistance plasmids have been described in P. multocida from turkeys [29]. In the latter case mobilisation occurred not only into other P. multocida isolates, but also into E. coli. A conjugative plasmid which mediated resistance to tetracyclines, 
streptomycin, sulfonamides and kanamycin also proved to be able to move into other $P$. multocida and E. coli strains and to express its resistance properties in both host bacteria [31]. Another possibility of horizontal transfer of small plasmids is by transduction. This way is however limited by the amount of DNA that can be packaged into a phage head and the requirement for specific receptors for phage attachment on the surface of the new host cells. These receptors are usually only present among cells of the same or closely related species within the same genus. Although phages have been detected in pasteurellae, very little is known about transducing phages in Pasteurella and Mannheimia [33, 42].

The fate of a resistance plasmid introduced into a new host cell is uncertain. In the most simple case, this plasmid is able to stably replicate and express its resistance properties in the new host cell. This has been observed with many resistance plasmids from Pasteurella and Mannheimia when introduced into $E$. coli host cells. However, plasmids of Enterobacteriaceae which harbour a ColE1 replication origin proved to be replication-deficient in Pasteurella or Mannheimia host cells [5]. There are also several known "broad host range" plasmids which have shown to be able to replicate in many different bacteria. Some of these plasmids, such as R100 (database accession no. AP000342), carry copies of the small nonconjugative resistance transposons $\operatorname{Tn} 9$ (catAI) or $\operatorname{Tn} 10(\operatorname{tet}(\mathrm{B}))$ and by their spread also promote the spread of these resistance transposons. Even if the plasmid itself may be replication-deficient in a new host, its transposons can excise and integrate into plasmids and the chromosomal DNA of the new host cell. This might be an explanation for the occurrence of Tn10 copies in the chromosome of $P$. aerogenes isolates [37]. Plasmid incompatibility between the transferred resistance plasmids and those plasmids still resident in the new host cell may negatively influence the stable maintenance of the newly acquired resistance plasmids. In addition, Pasteurella and Mannheimia cells may also harbour restriction/modification systems which protect the cell from foreign DNA. Such host cell defense systems have been described to occur in P. multocida [32] and "P. haemolytica" [28].

Simple and efficient ways for transferred resistance plasmids to circumvent potential problems arising from replication deficiency, plasmid incompatibility or destruction by restriction systems are (a) the integration in part or in toto - into the chromosomal DNA of the new host cell, but also (b) the fusion with or the integration into plasmids of the new host cell. In the latter case, novel plasmids are formed which carry additional resistance genes and are able to replicate in the new host cell. A single copy of a resistance gene in the chromosomal DNA bears the problem that this gene may be functionally deleted as the result of mutations, recombinations or insertions. However, the presence of Pasteurella and Mannheimia isolates in a polymicrobial environment offers the opportunity to acquire new resistance genes from the respective gene pool by horizontal gene transfer mechanisms [19]. Thus bacteria may acquire resistance genes which have developed in other bacteria but have been refined under selective pressure. With regard to an optimised function in the new host, the resistance genes may be subjected to slight modifications resulting in few amino acid exchanges in the respective resistance gene products as mentioned in Sections 4.3.2-4.3.5. Most of the resistance genes currently known to occur in Pasteurella and Mannheimia, such as tet(B), catAI, catAIII, sulII, or strA, are most likely of enterobacterial origin, but have gained access to bacteria living in other environmental compartments such as the respiratory tract. Others, such as $b l a_{\mathrm{ROB} 1}$, seem to be widely distributed among respiratory pathogens and a gene like $\operatorname{tet}(\mathrm{H})$ seems to be limited to Pasteurella and Mannheimia isolates present in the respiratory tract. On the one hand, it is observed that $P$. aerogenes isolates from the intestinal tract mainly 
harbour tet(B) genes - which are the most predominant tet genes among Enterobacteriaceae. On the other hand, $P$. multocida isolates from the respiratory tract almost exclusively carry tet $(\mathrm{H})$ genes. This underlines the role of the gene pools present in certain environments, such as the intestinal or the respiratory tract, for the acquisition of resistance genes by bacteria of different species and genera [37].

\section{CONCLUSION}

Isolates of the genera Pasteurella and Mannheimia are still among the most economically important veterinary bacterial pathogens. Due to the often unsatisfying or even ineffective immunoprophylactic measures taken, antimicrobials are used to a large extent for prophylaxis, metaphylaxis or the therapy of diseases in which Pasteurella and Mannheimia isolates are involved. Although improved vaccines are under development, the current principles of antibiotic use in the control of infections due to Pasteurella and Mannheimia need to be refined according to prudent use guidelines. Molecular analysis has provided insight into the variety of resistance genes so far known to be present in Pasteurella and Mannheimia isolates. Most of these resistance genes are associated with mobile genetic elements and, can thus easily be exchanged between bacteria. The occurrence of these resistance genes in a wide range of bacteria implies that Pasteurella and Mannheimia isolates have access to large gene pools within which an interchange of resistance genes takes place. Recent studies confirmed that some of the resistance genes encountered in Pasteurella and Mannheimia such as catAIII and sulII, are widely distributed in Enterobacteriaceae and other gram-negative bacteria, while other genes such as $\operatorname{tet}(\mathrm{M})$ and $b_{\text {bOB } 1}$, appear to demonstrate links between gram-negative and gram-positive bacteria. The current knowledge of resistance genes and their ways of spreading, as described for the resistance genes mentioned in this review, leads to the assumption that resistance development in Pasteurella and Mannheimia isolates is a continuous process in which novel resistance genes may be acquired or developed under the selective pressure imposed by the use of new drugs.

Although animal pasteurellosis has only limited consequences for public health, it would be hazardous to stop or to maintain the monitoring of resistance of Pasteurella and Mannheimia isolates at only a low level. Monitoring antimicrobial resistance is essential to assist practitioners in the rational selection of antimicrobial agents and the prudent use of these drugs. Recent results on the evolution of antibiotic resistance in Pasteurella and Mannheimia call for a reinforcement of monitoring at the national and international levels. This also implies the development of rapid and reliable tests for species identification of these bacteria and antimicrobial sensitivity testing, as well as the development of new vaccines to effectively prevent pneumonic diseases in foodproducing animals and thus reduce the overall use of antimicrobial agents.

\section{ACKNOWLEDGMENTS}

The authors wish to thank Erika Nußbeck, Vera Nöding and Gisela Niemann for expert technical assistance in many studies mentioned in this review.

\section{REFERENCES}

[1] Alton N.K., Vapnek D., Nucleotide sequence analysis of the chloramphenicol resistance transposon $\operatorname{Tn} 9$, Nature 282 (1979) 864-869.

[2] Angen Ø., Caugant D.A., Olsen J.E., Bisgaard M., Genotypic relationships among strains classified under the (Pasteurella) haemolytica-complex as indicated by ribotyping and multilocus enzyme electrophoresis, Zentralbl. Bakteriol. 286 (1997) 333-354.

[3] Angen Ø., Mutters R., Caugant D.A., Olsen J.E., Bisgaard M., Taxonomic relationships of the [Pasteurella] haemolytica complex as evaluated by 
DNA-DNA hybridizations and 16S rRNA sequencing with proposal of Mannheimia haemolytica gen. nov., comb. nov., Mannheimia granulomatis comb. nov., Mannheimia glucosida sp. nov., Mannheimia ruminalis sp. nov. and Mannheimia varigena sp. nov., Int. J. Syst. Bacteriol. 49 (1999) 67-86.

[4] Azad A.K., Coote J.G., Parton R., Distinct plasmid profiles of Pasteurella haemolytica serotypes and the characterization and amplification in $E$. coli of ampicillin-resistance plasmids encoding ROB1-ß-lactamase, J. Gen. Microbiol. 138 (1992) 1185-1196.

[5] Azad A.K., Coote J.G., Parton R., Construction of conjugative shuttle and suicide vectors for Pasteurella haemolytica and Pasteurella multocida, Gene 145 (1994) 81-85.

[6] Berman S.M., Hirsh D.C., Partial characterization of R-plasmids from Pasteurella multocida isolated from turkeys, Antimicrob. Agents Chemother. 14 (1978) 348-352.

[7] Biberstein E.L., Pasteurella, in: Biberstein E.L., Zee Y.C. (Eds.), Review of Veterinary Microbiology, Blackwell Scientific Publications, Boston, Oxford, 1990, pp. 175-180.

[8] Blackall P.J., Miflin J.K., Identification and typing of Pasteurella multocida: a review, Avian Pathol. 29 (2000) 271-287.

[9] Caprioli A, Busani L, Martel J.L., Helmuth R., Monitoring of antibiotic resistance in bacteria of animal origin: epidemiological and microbiological methodologies, Int. J. Antimicrob. Agents, 14 (2000) 295-301.

[10] Chalmers S., Sewitz R., Lipkow K., Crellin P., Complete nucleotide sequence of $\operatorname{Tn} 10$, J. Bacteriol. 182 (2000) 2970-2972.

[11] Chang Y.F., Renshaw H.W., Young R., Pneumonic pasteurellosis: examination of typeable and untypeable Pasteurella haemolytica strains for leucotoxin production, plasmid content, and antimicrobial susceptibility, Am. J. Vet. Res. 48 (1987) 378-384

[12] Chang Y.F., Ma D.P., Bai H.Q., Young R., Struck D.K., Shin S.J., Lein D.H., Characterization of plasmids with antimicrobial resistance genes in Pasteurella haemolytica A1, DNA Seq. 3 (1992) 89-97.

[13] Chaslus-Dancla E. Lesage-Descauses M.-C., Leroy-Sétrin S., Martel J.-L., Lafont J.-P., Tetracycline resistance determinants, TetB and TetM, detected in Pasteurella haemolytica and Pasteurella multocida from bovine herds, J. Antimicrob. Chemother. 36 (1995) 815-819.

[14] Chaslus-Dancla E., Lesage-Descauses M.-C., Leroy-Sétrin S., Martel J.-L., Coudert P., Lafont J.P., Validation of random amplified polymorphic DNA assays by ribotyping as tools for epidemiological surveys of Pasteurella from animals, Vet. Microbiol. 52 (1996) 91-102.

[15] Clewell D.B., Flannagan S.E., The conjugative transposons of Gram-positive bacteria, in: Clewell
D.B. (Ed.), Bacterial conjugation, Plenum Press, New York, 1993, pp. 369-393.

[16] Cote S., Harel J., Higgins R., Jacques M., Resistance to antimicrobial agents and prevalence of $\mathrm{R}$ plasmids in Pasteurella multocida from swine, Am. J. Vet. Res. 52 (1991) 1653-1657.

[17] Craig F.F., Coote J.G., Parton R., Freer J.H., Gilmour N.J.L., A plasmid which can be transferred between Escherichia coli and Pasteurella haemolytica by electroporation and conjugation, J. Gen. Microbiol. 135 (1989) 2885-2890.

[18] Dabernat H., Delmas C., Livrelly V., Joly B., Résistance clinique à l'ampicilline par production de Béta-lactamase chez Haemophilus influenzae, Méd. Mal. Infect. Hors série, mai (1989) 7985.

[19] DeFlaun M.F., Levy S.B., Genes and their varied hosts, in: Levy S.B., Miller R.V. (Eds.), Gene transfer in the environment, McGraw-Hill, New York, 1989, pp. 1-32.

[20] Dewhirst F.E., Paster B.J., Olsen I., Fraser G.J., Phylogeny of 54 representative strains of species in the family Pasteurellaceae as determined by comparison of 16S rRNA sequences, J. Bacteriol. 174 (1992) 2002-2013.

[21] Donachie W., Bacteriology of bovine respiratory disease, Cattle Practice 8 (2000) 5-7.

[22] Escande F., Gerbaud G., Martel J.-L., Courvalin P., Resistance to trimethoprim and 2,4-diamino6,7-diisopropyl-pteridine (O/129) in Pasteurella haemolytica, Vet. Microbiol. 26 (1991) 107-114.

[23] Euzéby J.P., List of bacterial names with standing in nomenclature: a folder available on the Internet (last updated: March 2000, URL: http://www. bacterio.cict.fr), Int. J. Syst. Bacteriol. 47 (1997) 590-592.

[24] Gardner I.A., Kasten R., Eamens G.J., Snipes K.P., Anderson R.J., Molecular fingerprinting of Pasteurella multocida associated with progressive atrophic rhinitis in swine herds, J. Vet. Diagn. Invest. 6 (1994) 55-58.

[25] Gauthier G., Lafay B., Ruimy R., Breittmayer V., Nicolas J.L., Gauthier M., Christen R., Small subunit rRNA sequences and whole DNA relatedness concur for the reassignment of Pasteurella piscicida (Snieszko et al.) Janssen and Surgalla to the genus Photobacterium as Photobacterium damsela subsp. piscicida comb. nov., Int. J. Syst. Bacteriol. 45 (1995) 139-144.

[26] Hansen L.M., McMurray L.M., Levy S.B., Hirsh D.C., A new tetracycline resistance determinant, TetH, from Pasteurella multocida specifying active efflux of tetracycline, Antimicrob. Agents Chemother. 37 (1993) 2699-2705.

[27] Hansen L.M., Blanchard P.C., Hirsh D.C., Distribution of tet $(\mathrm{H})$ among Pasteurella isolates from the United States and Canada, Antimicrob. Agents Chemother. 40 (1996) 1558-1560.

[28] Highlander S.K., Garza O., The restrictionmodification system of Pasteurella haemolytica 
is a member of a new family of type I enzymes, Gene 178 (1996) 89-96.

[29] Hirsh D.C., Martin D.L., Rhoades K.R., Conjugal transfer of an R-plasmid in Pasteurella multocida, Antimicrob. Agents Chemother. 20 (1981) 415-417.

[30] Hirsh D.C., Martin D.L., Rhoades K.R., Resistance plasmids of Pasteurella multocida isolated from turkeys, Am. J. Vet. Res. 46 (1985) 14901493.

[31] Hirsh D.C., Hansen L.M., Dorfman L.C., Snipes K.P., Carpenter T.E., Hird D.W., McCapes R.H., Resistance to antimicrobial agents and prevalence of R plasmids in Pasteurella multocida from turkeys, Antimicrob. Agents Chemother. 33 (1989) 670-673

[32] Hoskins I.C., Lax A.J., Identification of restriction barriers in Pasteurella multocida, FEMS Microbiol. Lett. 156 (1997) 223-226.

[33] Hunt M.L., Adler B., Townsend K.M., The molecular biology of Pasteurella multocida, Vet. Microbiol. 72 (2000) 3-25.

[34] Juteau J.-M., Sirois, M., Medeiros A.A., Levesque R.C., Molecular distribution of ROB1- $\beta$-lactamase in Actinobacillus pleuropneumoniae, Antimicrob. Agents Chemother. 35 (1991) 13971402.

[35] Kehrenberg C., Molecular basis of tetracycline resistance among isolates of the genera Pasteurella and Mannheimia: identification of novel plasmids and transposons, Ph.D. thesis, Hannover School of Veterinary Medicine, 2000, pp. 1-265.

[36] Kehrenberg C., Schwarz S., Identification of a truncated, but functionally active tet $(\mathrm{H})$ tetracycline resistance gene in Pasteurella aerogenes and Pasteurella multocida, FEMS Microbiol. Lett. 188 (2000) 191-195.

[37] Kehrenberg C., Schwarz S., Genetic basis of tetracycline resistance in Pasteurella aerogenes, Abstracts of the 40th Interscience Conference on Antimicrobial Agents and Chemotherapy (ICAAC), ASM Press, Washington, 2000, p. 130.

[38] Kehrenberg C., Werckenthin C., Schwarz S., Tn5706, a transposon-like element from Pasteurella multocida mediating tetracycline resistance, Antimicrob. Agents Chemother. 42 (1998) 2116-2118.

[39] Kehrenberg C., Watts J.L., Schwarz S., Identification of a truncated Tn5706 element on structurally related plasmids of Mannheimia haemolytica and Pasteurella multocida, Abstracts of the 39th Interscience Conference on Antimicrobial Agents and Chemotherapy (ICAAC), ASM Press, Washington, 1999, p. 102.

[40] Kim E.H., Aoki T., Sequence analysis of the florfenicol resistance gene encoded in the transferable R-plasmid of a fish pathogen, Pasteurella piscicida, Microbiol. Immunol. 40 (1996) 665669.

[41] Kodjo A., Villard L., Bizet C., Martel J.L., Sanchis R., Borges E., Gauthier D., Maurin F.,
Richard Y., Pulsed-field gel electrophoresis is more efficient than ribotyping and random amplified polymorphic DNA analysis in discrimination of Pasteurella haemolytica strains, J. Clin. Microbiol. 37 (1999) 380-385.

[42] Kokjohn T.A., Transduction: Mechanism and potential for gene transfer in the environment, in: Levy S.B., Miller R.V. (Eds.), Gene transfer in the environment, McGraw-Hill, New York, 1989, pp. 73-97.

[43] Koneman E.W., Allen S.D., Janda W.M., Schreckenberger P.C., Winn W.C. Jr., Color atlas and textbook of diagnostic microbiology, 5th ed., Lippincott, Philadelphia, New York, 1997, pp. 416-423.

[44] Livrelli V.O., Darfeuille-Richaud A., Rich C., Joly B.H., Martel J.-L., Genetic determinant of the ROB-1 $\beta$-lactamase in bovine and porcine Pasteurella strains, Antimicrob. Agents Chemother. 32 (1988) 1282-1284.

[45] Livrelli V.O., Peduzzi J., Joly B., Sequence and molecular characterization of the ROB1- $\beta$-lactamase gene from Pasteurella haemolytica, Antimicrob. Agents Chemother. 35 (1991) 242-251.

[46] Martel J.L., Sanchis R., Fréquences des sérotypes de Pasteurella haemolytica isolés chez les bovins en France, in: Espinasse J. (Ed.), Réunion de la Société Française de Buiatrie, 29-30 novembre 1995, Paris, p. 1-3.

[47] Martel J.L., Chaslus-Dancla E., Coudert M., Poumarat F., Lafont J.P., Survey of antimicrobial resistance in bacterial isolates from diseased cattle in France, Microb. Drug Resist. 1 (1995) 273-283.

[48] Medeiros A.A., Levesque R.C., Jacoby G.A., An animal source for the ROB1- $\beta$-lactamase of Haemophilus influenzae type $\mathrm{b}$, Antimicrob. Agents Chemother. 29 (1986) 212-215.

[49] Murphy G.L., Robinson L.C., Burrows G.E., Restriction endonuclease analysis and ribotyping differentiate Pasteurella haemolytica serotype A1 isolates from cattle within a feedlot, J. Clin. Microbiol. 131 (1993) 2303-2308.

[50] Mutters R., Ihm I., Pohl S., Frederoksen W., Mannheim W., Reclassification of the Genus Pasteurella Trevisan 1887 on the basis of deoxyribonucleic acid homology, with proposals for the new species Pasteurella dagmatis, Pasteurella canis, Pasteurella stomatis, Pasteurella anatis, and Pasteurella langaa, Int. J. Syst. Bacteriol. 35 (1985) 309-322.

[51] Philippon A., Joly B., Reynaud D., Paul G., Martel J.L., Sirot D., Cluzel R., Nevot P., Characterization of a beta-lactamase from Pasteurella multocida, Ann. Inst. Pasteur Microbiol. A 137 (1986) 153-158.

[52] Purdy C.W., Raleigh R.H, Collins J.K., Watts J.L., Straus D.C., Serotyping and enzyme characterization of Pasteurella haemolytica and Pasteurella multocida isolates recovered from 
pneumonic lungs of stressed feeder calves, Curr. Microbiol. 34 (1997) 244-249.

[53] Radostits O.M., Gay C.., Blood D.C., Hinchcliff K.W., A textbook of the diseases of cattle, sheep, pigs, goats, and horses, 9th ed., Saunders, Philadelphia, London, 2000, pp. 829-867.

[54] Rosenau A., Labigne A., Escande F., Courcoux P., Philippon A., Plasmid-mediated ROB1-ß-lactamase in Pasteurella multocida from human specimen, Antimicrob. Agents Chemother. 35 (1991) 2419-2422.

[55] Rossmanith S.E.R., Wilt G.R., Wu G., Characterization and comparison of antimicrobial susceptibilities and outer membrane protein and plasmid DNA profiles of Pasteurella haemolytica and certain other members of the genus Pasteurella, Am. J. Vet. Res. 52 (1991) 2016-2022.

[56] Schulze-Tanzil G., Studies on antimicrobial resistance of bovine and porcine Pasteurella isolates with particular reference to resistances against $\beta$-lactams, tetracyclines and chloramphenicol as well as to the detection of resistance plasmids in selected isolates, Free University of Berlin, Doctoral Thesis, 1999, pp. 1-205.

[57] Schwarz S., Spies U., Reitz B., Seyfert H.-M., Lämmler C., Blobel H., Detection and interspecies-transformation of a $\beta$-lactamase-encoding plasmid from Pasteurella haemolytica, Zentralbl. Bakteriol. Mikrobiol. Hyg. A 270 (1989) 462469.

[58] Schwarz S., Spies U., Schäfer F., Blobel H., Isolation and interspecies-transfer of a plasmid from Pasteurella multocida encoding streptomycin resistance, Med. Microbiol. Immunol. 178 (1989) 121-125.

[59] Silver, R.P., Leming B., Garon C.F., Hjerpe C.A., R-plasmids in Pasteurella multocida, Plasmid 2 (1979) 493-497.
[60] Theuretzbacher U., $\beta$-Lactamases and $\beta$-lactamase inhibitors, Chemother. J. 7 (1998) 136-142.

[61] Trolldenier H., Resistenzauswertung veterinärmedizinisch bedeutsamer bakterieller Erreger 1990, Vet. med. Heft 3/1992, Robert-OstertagInstitut, Berlin, 1992.

[62] Trolldenier H., Resistenzauswertung veterinärmedizinisch bedeutsamer bakterieller Erreger 1992. BgVV-Heft 2/1995, 1995.

[63] Trolldenier H., Resistenzauswertung veterinärmedizinisch bedeutsamer bakterieller Erreger 1993. BgVV-Heft 10/1995, 1995.

[64] Trolldenier H., Resistenzentwicklung der häufigsten bakteriellen Krankheitserreger bei landwirtschaftlichen Nutztieren. Veterinärspiegel 3, Sonderheft: 5., Bernburger Kolloquium "Antimikrobielle Therapie beim landwirtschaftlichen Nutztier", Beto Verlag, Bonn, 1997.

[65] Trolldenier H., Antimikrobielle Tierarzneimittel: Resistenzentwicklung und Monitoring. Aktuelle Diskussion - Antibiotikaresistenz, Tagungsbericht des 23. Kongresses der Deutschen Veterinärmedizinischen Gesellschaft, 1999, pp. 3-17.

[66] Vassort-Bruneau C., Lesage-Decauses M.-C., Martel J.-L., Lafont J.-P., Chaslus-Dancla E., CAT III chloramphenicol resistance in Pasteurella haemolytica und Pasteurella multocida isolated from calves, J. Antimicrob. Chemother. 38 (1996) 205-213.

[67] Yamamoto J., Sakano T., Shimizu M., Drug resistance and R plasmids in Pasteurella multocida from swine, Microbiol. Immunol. 34 (1990) 715721.

[68] Zimmerman M.L., Hirsh D.C., Demonstration of an R-plasmid in a strain of Pasteurella haemolytica isolated from feedlot cattle, Am. J. Vet. Res. 41 (1980) 166-169. 